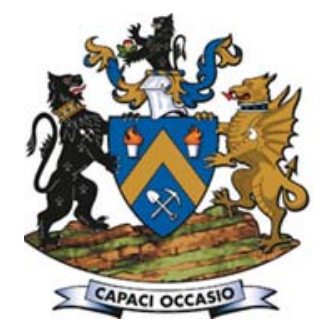

\title{
An improved flotation test method and pyrite depression by an organic reagent during flotation in seawater
}

\author{
by R.I. Jeldres*, D. Calisaya*, and L.A. Cisternas*
}

\section{Synopsis}

Flotation of copper-molybdenum sulphide ores in seawater entails critical challenges such as selective recovery of molybdenite, effective pyrite depression, and reducing the lime addition required to reach highly alkaline conditions. It is essential that laboratory flotation tests aimed at solving these problems give reliable, reproducible results and indicate the correct approach for industrial operations. Rougher flotation of coppermolybdenum sulphide ores in seawater was investigated using two different cells: a modified Denver cell and a standard commercial cell. The effect of an organic reagent on the flotation performance was tested, and the fast/slow-floating model was used to describe the results. The modified Denver cell significantly improved the reproducibility of the flotation test results, due to technological enhancements such as the impeller being driven from below without a stator, which enables the whole froth surface to be scraped with a paddle at a constant depth and rate. Organic reagents are a promising alternative to inorganic reagents for depressing pyrite in seawater. However, further studies should be conducted to investigate their impact on molybdenite recovery, as well as to evaluate the possibility of depressing pyrite after molybdenite separation. The fast/slow-floating model was found to be appropriate for describing the flotation kinetics of the copper-molybdenum ores. The parameters are useful for comparing the performance at different conditions.

\section{Keywords}

flotation, seawater, modified Denver cell, organic pyrite depressant, fast/slow-floating model. unknown consequences. The direct use of seawater is, therefore, more attractive, but it also poses major challenges since seawater contains ions that adversely affect mineral recoveries. In particular, in the flotation of sulphide ores in seawater, the floatability of molybdenite is depressed (Castro, 2012; Laskowski, Castro, and Ramos, 2014). Copper recovery in flotation plants is usually in the range of $81-85 \%$ (Monardes, 2009), but even small improvements are important considering the large quantities of ores that are treated. Flotation of valuable minerals is assisted by the addition of several types of reagents, the most important of which are collectors. For example, there are thiol collectors such as xanthates, dithiophosphates, thiocarbamates, and mercaptans (Veki, 2013). The primary objective of a collector is to adsorb onto the mineral surface to impart a hydrophobic character, while keeping gangue minerals in a hydrophilic form. Additionally, bubble coalescence in any saline water is hindered. Bournival, Pugh, and Ata (2011) noted that the effects of dissolved salts are still not understood, and the exact mechanism is a matter of debate. Nevertheless, in highly saline media, the bubble size is influenced mainly by inorganic electrolytes, and the frother has only a minor effect (Laskowski, Castro, and Ramos, 2014). This is an important issue, considering that frothers might adsorb onto the hydrophobic mineral surfaces, decreasing their floatability (Kursun, 2014).

An essential requirement in sulphide flotation is to achieve a good level of pyrite depression, since pyrite diminishes the quality of the concentrate and increases the quantity of sulphur compounds produced in the base metal extraction processes. Pyrite depression is usually reached at highly alkaline conditions

\footnotetext{
* Depart of Chemical Engineering and Mineral Process, University of Antofagasta, Antofagasta, Chile.

(c) The Southern African Institute of Mining and Metallurgy, 2017. ISSN 2225-6253. Paper received Oct. 2016; revised paper received Mar. 2017.
} 


\section{An improved flotation test method and pyrite depression by an organic reagent}

( $\mathrm{pH}$ above 10.5), wherein the pyrite surface is covered by hydrophilic iron oxides such as $\mathrm{Fe}(\mathrm{OH})_{3}, \mathrm{Fe}(\mathrm{OH})_{2}$, or $\alpha$ FeOOH (Wang, 1989; Mermilled-Blondin et al., 2005). A high pH is commonly attained by lime addition, but the required amount is excessive due to the buffering effect of seawater, which increases the lime consumption by 5-10 times compared to fresh water (Castro, 2012; Veki, 2013). However, at pH values over 10.5 , both calcium and magnesium ions form colloidal hydroxides, carbonates, and sulphates, which are detrimental for the recovery of molybdenite, and the quality of the concentrate is reduced (Castro and Laskowski, 2011; Ramos, Castro, and Laskowski, 2013; Jeldres et al., 2017). Some researchers have proposed that these complexes might precipitate onto the molybdenite surfaces and render them hydrophilic (Parraguez, Bernal, and Cartagena, 2009; Lucay et al., 2015). For this reason, operating rougher flotation at $\mathrm{pH}$ values lower than 9 to avoid $\mathrm{MoS}_{2}$ depression has been recommended, with pyrite depression by alternative reagents. In this regard, the use of inorganic depressants such as cyanides, sulphites, or ferrocyanides has raised concerns on environmental grounds. Therefore, organic polymers have been studied, in view of their natural, biodegradability and non-toxicicity (Lopez-Valdivieso et al., 2004; Bicak et al., 2007; Liu et al., 2009; Bulut et al., 2011; Koleini, Abdollahy, and Soltani, 2012; Sarquís et al., 2014; Mu, Peng, and Lauten, 2015). However, there is currently a lack of knowledge about the interaction between these additives and solid surfaces in highly saline environments. Some studies have shown that reagent behaviour in saline solutions depends on the type of salt in solution (maker or breaker), and the electrical charge of both the solid surface and the reagents (Hancer, Celik, and Miller, 2000; Jeldres et al., 2014). For a complete review of the use of saline water and seawater in flotation, see Jeldres, Forbes, and Cisternas (2016).

Consequently, the objectives of this paper are to (i) evaluate the rougher flotation of copper-molybdenum sulphide ores in seawater with different reagents, including an organic pyrite depressant, and (ii) compare the reproducibility of the results using two types of flotation cell: a modified Denver cell and standard commercial cell. The CSIRO has developed a novel flotation cell that corresponds to a modified Denver cell. The impeller and shaft are driven from below the cell, which allows the whole surface of the froth to be scraped with a paddle at constant depth and rate (Forbes, Davey, and Smith, 2014). The cell is fitted with a rubber diaphragm, sight tube, and electronic sensor for automatic detection and control of the pulp level (Forbes,
Table I

Composition of seawater from the city of Antofagasta, Chile (Ordoñes et al., 2013)

\begin{tabular}{|l|l|l|l|l|l|}
\hline Anions & $\mathbf{g} / \mathbf{l}$ & Mol/l & Cations & $\mathbf{g} / \mathbf{l}$ & Mol/l \\
\hline $\mathrm{NO}_{3}^{-}$ & 0.21 & 0.0034 & $\mathrm{Na}^{+}$ & 11.124 & 0.4837 \\
$\mathrm{SO}_{4}^{2-}$ & 2.66 & 0.0277 & $\mathrm{~K}^{+}$ & 0.361 & 0.0093 \\
$\mathrm{IO}_{3}^{-}$ & 0 & 0.0000 & $\mathrm{Mg}^{2+}$ & 1.576 & 0.0649 \\
$\mathrm{Cl}^{-}$ & 19.71 & 0.5560 & $\mathrm{Ca}^{2+}$ & 0.171 & 0.0043 \\
$\mathrm{ClO}_{4}^{-}$ & 0.12 & 0.0012 & & & \\
$\mathrm{BO}_{3}^{3-}$ & 0.16 & 0.0027 & & & \\
\hline
\end{tabular}

Davey, and Smith, 2014). Koh and Smith (2011) have used computational fluid dynamics (CFD) to describe the effect of stirring speed in this cell. Finally, a new parameter obtained from the fast/slow-floating model is proposed as an indicator of the 'global flotation performance.'

\section{Methodology}

Seawater flotation of copper-molybdenum sulphide minerals was carried out in two different flotation cells: (i) the modified Denver cell developed by CSIRO, and (ii) a standard commercial cell. The impact of various reagents, including an organic pyrite depressant, was investigated. Finally, the flotation kinetic was modelled by using the fast/slow-floating model. All tests were performed in duplicate to ensure good reproducibility of the results. Seawater from the coast in the vicinity of Antofagasta, Chile was used. Its composition is shown in Table I.

\section{Mineral samples}

Copper-molybdenum sulphide ore samples were acquired from a mining operation in the Antofagasta region. Chemical analysis indicated that the elemental composition was $\mathrm{Cu}$ : $0.55 \%$, Mo: $0.010 \%$, Fe: $4.26 \%$. Chalcopyrite is the main copper-bearing mineral.

\section{Flotation reagents}

Two different set of reagents, based on xanthate (set 1) and isothiazole (set 2) as primary collectors, were tested (Table II). The best option set (set 1) was used to evaluate the effect of an organic pyrite depressant obtained from corn (Oxi 300, $50 \mathrm{~g} / \mathrm{t})$.

\section{Flotation tests}

The ore was ground in a ceramic mill for 11.9 minutes to a size distribution of $\mathrm{P}_{80}<170 \mu \mathrm{m}$. The ground samples were transferred into the batch cell and made up to a volume of

\begin{tabular}{|l|l|l|l|}
\hline \multicolumn{4}{|l|}{$\begin{array}{l}\text { Table II } \\
\text { Reagents employed in flotation tests }\end{array}$} \\
\hline Set 1 & Set 2 & Dose (g/t) \\
\hline Reagent & Dose (g/t) & Reagent & 45 \\
\hline Oxi-2650 (primary xanthate collector) & 45 & Oxi-320B (primary isothazole collector) & 22 \\
Oxi-41 (secondary dithiophosphate collector) & 22 & Oxi-41 (secondary dithiophodphate collector) & 30 \\
Oxi-92 (frother) & 30 & Oxi-92 (frother) & 30 \\
\hline
\end{tabular}




\section{An improved flotation test method and pyrite depression by an organic reagent}

$2750 \mathrm{ml}$, giving a flotation pulp density of $30 \mathrm{wt} \%$. The reagents were all added 5 minutes before the start of flotation. The flotation gas was air at a flow rate of $81 / \mathrm{min}$, producing $0.70 \mathrm{~cm} / \mathrm{s}$ superficial air velocity. Froth depth of the order of $1 \mathrm{~cm}$ was scraped every 10 seconds during the test, and the concentrate was collected in trays.

\section{Modelling}

The fast/slow-floating particles model was used to describe the flotation kinetics. The model is expressed as:

$$
R(t)=R_{\infty}\left(\varnothing\left(1-\exp \left(-k_{f} t\right)\right)+(1-\emptyset)\left(1-\exp \left(-k_{s} t\right)\right)\right.
$$

where $R(t)$ is the recovery as a function of time $t, \varnothing$ is the fraction of flotation components with a fast rate constant, and $k_{f}$ and $k_{s}$ are the rate constants for fast and slow components respectively.

The parameter $K$ is defined as:

$$
K=R_{\infty}\left(\emptyset k_{f}+(1-\emptyset) k_{s}\right)^{n}
$$

where $n$ is a weighting index for the flotation rate constants. In this work, $n=0.1$. Besides the modified flotation parameter defined by Ucurum and Bayat (2007), the indicator $K$ defined here is useful for selecting the optimum flotation performance since it describes the global flotation performance, considering both maximum recovery and flotation rate. Note that to obtain the indicator $K$ all the parameters in Equation [1] are used.

The Effronís pseudo-R-squared measured was used as goodness of fit (GoF), that is,

$$
\text { GoF }=1-\frac{\sum_{i=1}^{N}\left(R_{i}^{e x p}-R_{i}^{\text {mod }}\right)^{2}}{\sum_{i=1}^{N}\left(R_{i}^{\text {exp }}-\bar{R}\right)^{2}}
$$

where $N$ is the number of data values and $\bar{R}$ the mean of $R$. Predicted flotation kinetic curves from each model were compared with the experimental data.

\section{Results and discussion}

\section{Flotation in highly alkaline conditions}

The buffering effect of seawater (Figure 1) starts at pH 10.2,

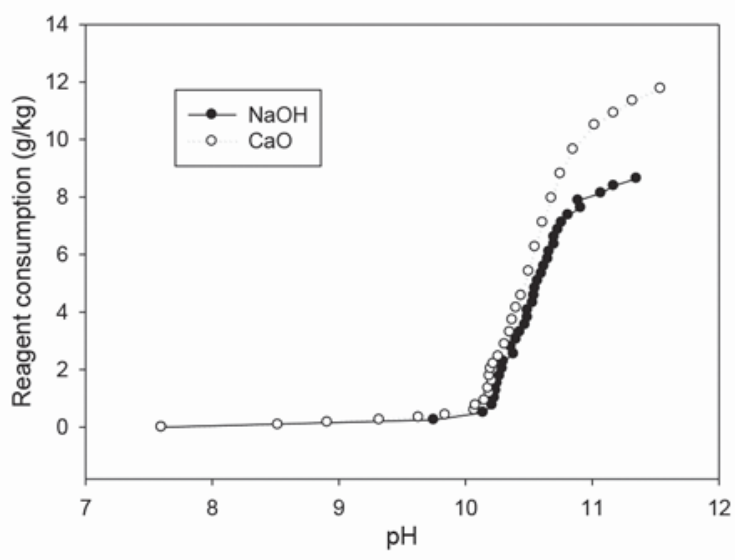

Figure 1-Lime $(\mathrm{CaO})$ and sodium hydroxide $(\mathrm{NaOH})$ required to modify $\mathrm{pH}$ in the rougher flotation of copper sulphide in seawater

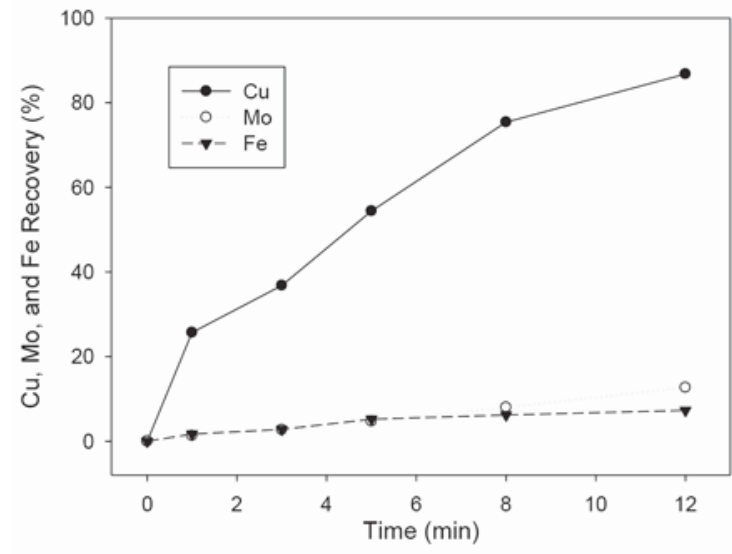

Figure 2- $\mathrm{Cu}, \mathrm{Mo}$, and $\mathrm{Fe}$ recoveries by flotation in seawater at $\mathrm{pH} 11.5$ modified with lime $(\mathrm{CaO})$

and the $\mathrm{CaO}$ and $\mathrm{NaOH}$ consumption is strongly increased, discouraging operation at this condition. It is also observed that at $\mathrm{pH}$ approximately 11 , around $25 \%$ more $\mathrm{CaO}$ than $\mathrm{NaOH}$ is required. Additionally, the recovery of molybdenum is poor (Figure 2). Therefore the usual strategy entails maximizing the copper and molybdenum recoveries in the rougher stage, working at a $\mathrm{pH}$ near 8 , and rejecting the pyrite in the rougher concentrate in the cleaner stage.

\section{Effect of reagents}

The effects of two primary copper collectors (Oxi 2650 and Oxi 320B) on seawater flotation of chalcopyrite, molybdenite, and pyrite were compared. A secondary collector (Oxi 41) and frother (Oxi 92) were also incorporated (details in Table II). The experiments were performed at natural $\mathrm{pH}$ because this condition maximizes $\mathrm{Cu}$ and Mo recoveries. All tests were conducted in duplicate to ensure good reproducibility.

Good recoveries of $\mathrm{Cu}$ and Mo were achieved, and the flotation kinetics were similar for both set of reagents. The chalcopyrite recovery after 12 minutes' flotation was $89.2 \%$ for reagent set 1 , and $89.5 \%$ for set 2 (Figure 3 ). For molybdenum, the recoveries were $79.6 \%$ for set 1 and $80.3 \%$ for set 2 (Figure 4). The pyrite recoveries were $33.9 \%$ for reagent set 1 and $36.6 \%$ for set 2 (Figure 5).

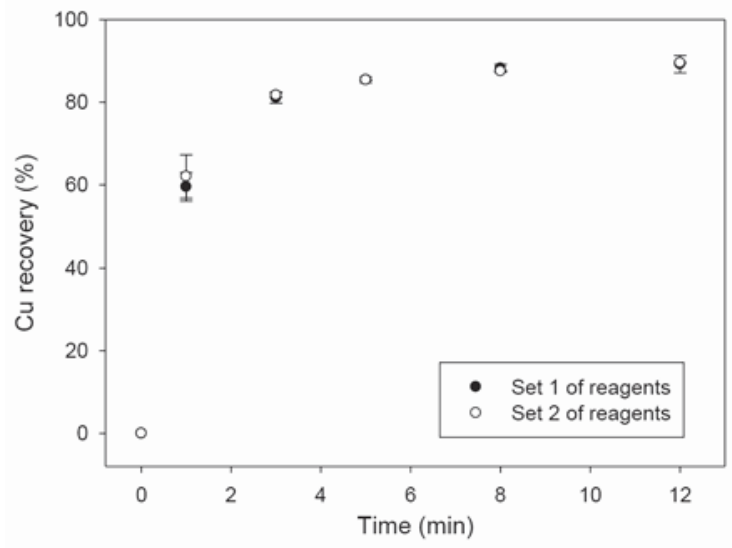

Figure 3-Cumulative copper recovery as a function of time for the two sets of reagents. Tests were performed in a modified Denver cell 


\section{An improved flotation test method and pyrite depression by an organic reagent}



Figure 4-Cumulative molybdenum recovery as a function of time for the two sets of reagents. Tests were performed in a modified Denver cell

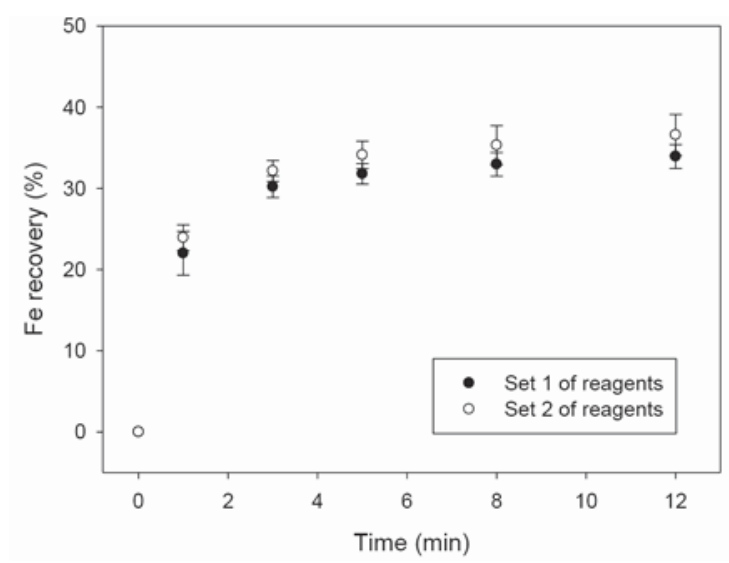

Figure 5-Cumulative iron recovery as a function of time for the two sets of reagents. Tests were performed in a modified Denver cell

Rougher flotation in seawater at natural $\mathrm{pH}$ offers promising benefits since a meaningful Mo recovery is obtained, and excessive lime consumption is avoided. However, at this condition, pyrite does not oxidize; it remains hydrophobic and reports to the concentrate, decreasing the concentrate grade. Therefore, finding new pyrite depressants would confer an advantage. A recommendable option is the use of organic reagents (López-Valdivieso et al., 2004; Bicak et al., 2007; Sarquís et al., 2014).

\section{Organic pyrite depressant}

An organic pyrite depressant obtained from corn (Oxi-300, $100 \mathrm{~g} / \mathrm{t}$ ) was incorporated in reagent set 1 . The flotation results are presented in Figures 6-8.

Figure 6 shows that Oxi-300 improves the flotation kinetics of copper slightly, but the ultimate recovery is similar with and without Oxi-300. Moreover, the recovery of pyrite after 12 minutes is reduced by $12.2 \%$ (from $38.5 \%$ to $26.3 \%$ ) by the addition of Oxi-300 (Figure 8 ). This encouraging result shows that organic pyrite depressants can be applied not only in fresh water, but also in seawater. However, Figure 7 indicates that this reagent has a detrimental effect on molybdenum floatability; the molybdenum recovery after 12 minutes for reagent set 1 was $78.1 \%$, decreasing to $71.0 \%$ in the presence of Oxi-300. Thus, although the use of organic reagents might be considered for pyrite depression in seawater flotation, further studies should be conducted to investigate the impact on the molybdenite recovery. Another alternative that should be explored is pyrite depression after molybdenite separation.

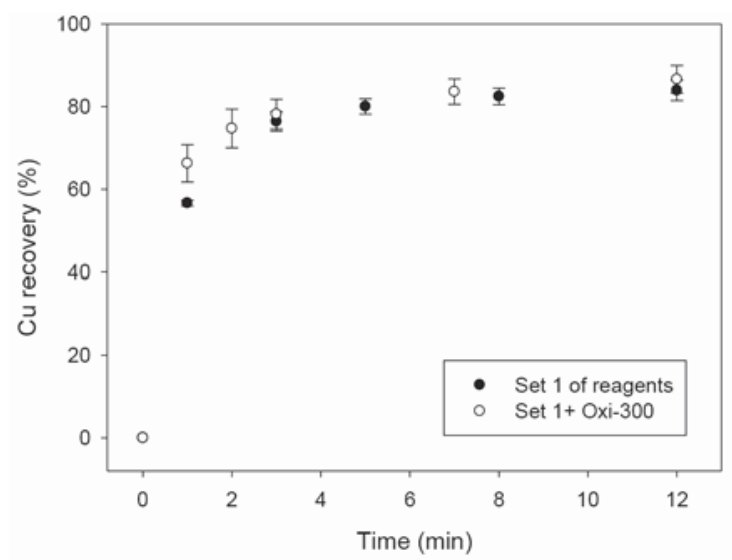

Figure 6-Impact of organic reagent on cumulative copper recovery as a function of time. Tests were performed in a commercial flotation cell

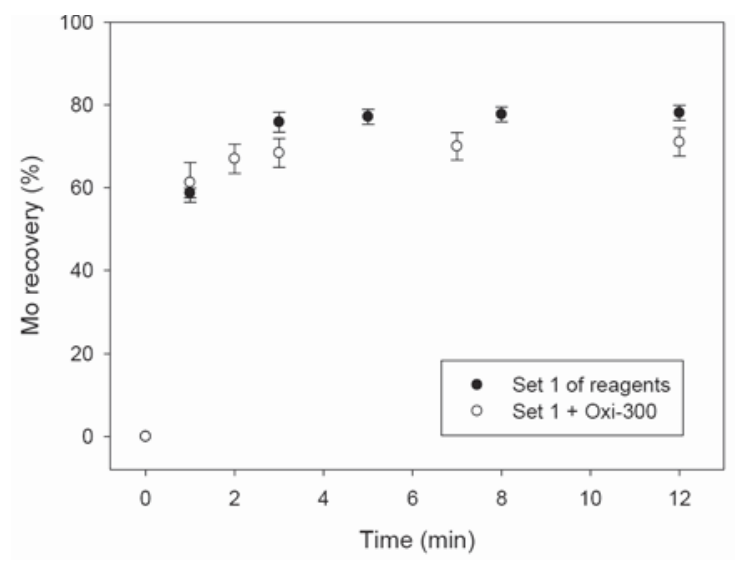

Figure 7-Impact of organic reagent on cumulative molybdenum recovery as a function of time. Tests were performed in a commercial flotation cell

\section{Modified Denver cell vs. commercial cell}

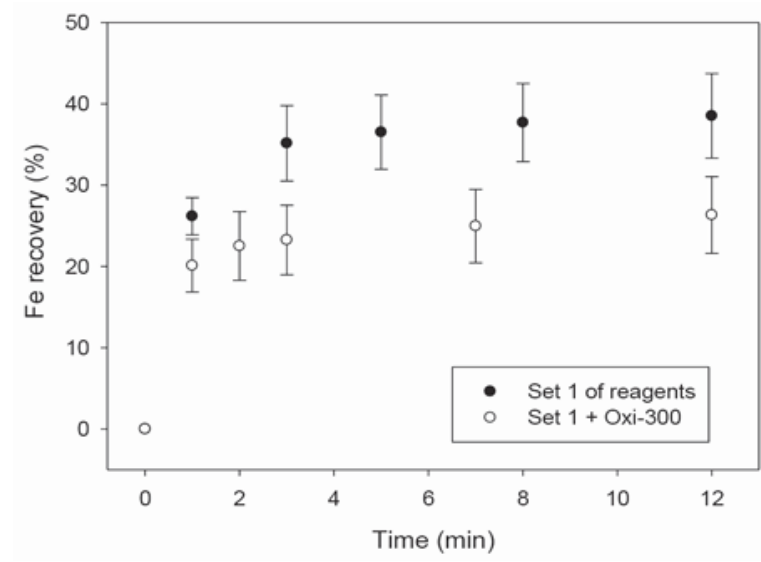

Figure 8-Impact of organic reagent on cumulative pyrite recovery as a function of time. Tests were performed in a commercial flotation cell 


\section{An improved flotation test method and pyrite depression by an organic reagent}

Figure 9 shows the standard deviations for the recoveries of $\mathrm{Cu}, \mathrm{Mo}$, and Fe after 12 minutes' flotation in the modified Denver cell and the commercial cell. Interestingly, higher standard deviations were always assigned to the conventional flotation cell, indicating that the experiments performed in the modified Denver cell have better reproducibility. This might be explained by the impeller and shaft configuration in the modified Denver cell, which are driven from below the cell, allowing the whole froth surface to be scraped with a paddle at a constant depth and rate. The automatic pulp level detection and control may also contribute to the reliability of the tests.

\section{Modelling}

Figures 10 and 11 show the fast/slow-floating model fitting (Equation [1]) for the flotation of copper in the modified Denver cell and commercial cell, respectively. The model was applied to all the tests previously reported, and the parameters are summarized in Tables III and IV.

The fast/slow-floating model captures very well the experimental data, and for all cases the goodness of fit (GoF) was higher than 0.999. The parameters obtained from the model (Tables III and IV) are used to calculate the indicator $K$ (Equation [2]), which represents the flotation kinetic global performance and includes both flotation rate and maximum recovery.

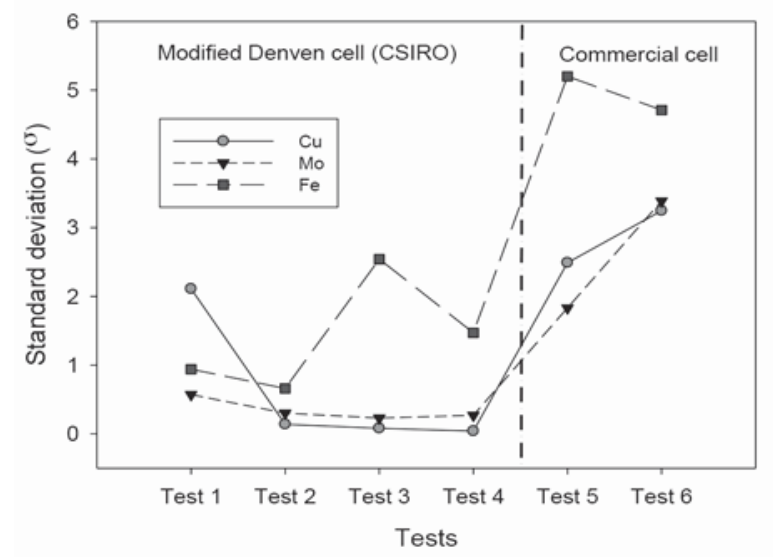

Figure 9-Comparison of reproducibility through the standard deviation for flotation tests in modified Denver cell (tests 1-4) and commercial cell (tests 5 and 6 )

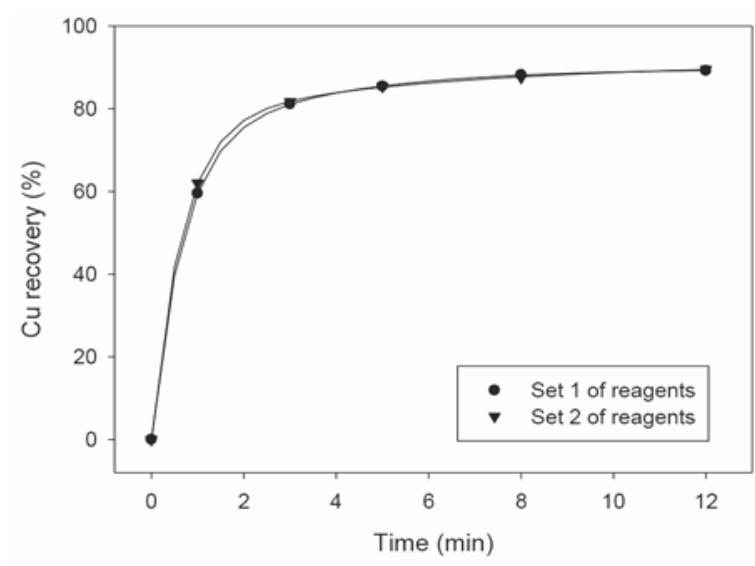

Figure 10-Flotation kinetics of copper in modified Denver cell. Symbols are experimental data, and solid curves are obtained by the fast/slowfloating model

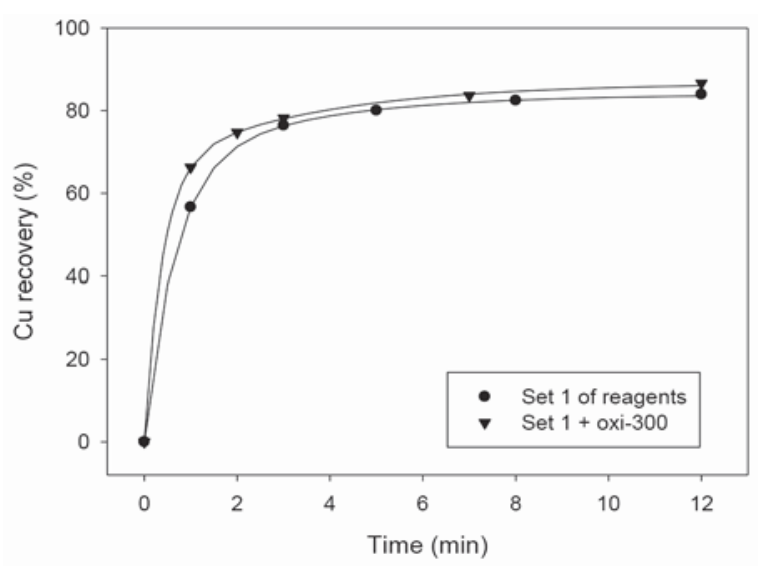

Figure 11-Flotation kinetics of copper in the commercial cell. Symbols are experimental data, and solid curves are obtained by the fast/slowfloating model

Table III

Parameters obtained by fitting the fast/slow-

floating particles model to experimental data. Tests performed at natural pH with two sets of reagents in modified Denver cell

\begin{tabular}{|l|l|l|l|l|l|}
\hline $\begin{array}{l}\text { Mineral-set } \\
\text { of reagents }\end{array}$ & $\boldsymbol{R}_{\infty}$ & $\boldsymbol{k}_{\boldsymbol{s}}$ & $\boldsymbol{k}_{\boldsymbol{f}}$ & $\boldsymbol{\phi}$ & $\boldsymbol{K}$ \\
\hline Cu-set 1 & 89.2 & 0.38 & 1.59 & 0.73 & 91.3 \\
Cu-set 2 & 89.5 & 0.29 & 1.60 & 0.81 & 92.3 \\
Mo-set 1 & 79.9 & 0.22 & 1.51 & 0.95 & 83.0 \\
Mo-set 2 & 81.0 & 0.15 & 1.67 & 0.95 & 84.8 \\
Fe-set 1 & 35.1 & 0.15 & 1.37 & 0.80 & 35.5 \\
Fe-set 2 & 37.7 & 0.16 & 1.49 & 0.78 & 38.4 \\
\hline
\end{tabular}

Table IV

Parameters obtained by fitting the fast/slowfloating model to experimental data. Tests performed at natural $\mathrm{pH}$ with set 1 of reagents and testing an organic pyrite depressant (0xi-300). Flotation tests conducted in the commercial cell

\begin{tabular}{|l|l|l|l|l|l|}
\hline $\begin{array}{l}\text { Mineral-set } \\
\text { of reagents }\end{array}$ & $\boldsymbol{R}_{\infty}$ & $\boldsymbol{k}_{\boldsymbol{s}}$ & $\boldsymbol{k}_{\boldsymbol{f}}$ & $\boldsymbol{\phi}$ & $\mathbf{s}$ \\
\hline Cu-set 1 & 83.9 & 0.32 & 1.54 & 0.78 & 86.9 \\
Cu-set 1+oxi-300 & 86.6 & 0.29 & 2.59 & 0.76 & 93.0 \\
Mo-set 1 & 78.1 & 0.30 & 1.56 & 0.95 & 81.3 \\
Mo-set 1+oxi-300 & 71.0 & 0.27 & 2.34 & 0.92 & 76.7 \\
Fe-set 1 & 38.5 & 0.27 & 1.51 & 0.81 & 39.5 \\
Fe-set 1+oxi-300 & 23.6 & 0.23 & 2.68 & 0.77 & 28 \\
\hline
\end{tabular}

From Table III it is seen that $K$ is very similar for $\mathrm{Cu}$ and Mo flotation kinetics. However, a small difference is noted for $\mathrm{Fe}$, where $K$ indicates that the global floatation performance is higher with reagent set 2 .

The values of $K$ obtained for the tests in the commercial cell (Table IV) indicate that the flotation kinetics of copper are benefited by the organic pyrite depressant, since $K$ increased from 86.9 to 93.0. In the case of molybdenum, $K$ was reduced from 81.3 to 76.7 , indicating that the organic reagent has a detrimental effect on global flotation performance. Moreover, it is proved that the reagent promotes pyrite depression, since $K$ decreased from 39.5 to 28.4 .

The fast/slow-floating model is thus appropriate to describe the flotation kinetics of copper-molybdenum ores in 


\section{An improved flotation test method and pyrite depression by an organic reagent}

seawater suspensions, since the GoF in all cases was higher than 0.999. Furthermore, the parameters obtained from the model can be useful for comparing the performance of each test under different conditions, wherein $K$ is treated as an indicator of the global flotation performance.

\section{Conclusions}

Rougher flotation tests of $\mathrm{Cu}-\mathrm{Mo}$ sulphide ores in seawater were carried out in two different flotation cells at the natural $\mathrm{pH}$ of the suspensions. This option avoids excessive lime consumption due to the buffering effect of seawater. However, a significant amount of pyrite is recovered, decreasing the quality of the concentrate. The main conclusions of this work are listed below.

$>$ High copper and molybdenum recoveries in seawater at natural $\mathrm{pH}$ were achieved with both xanthate and isothiazole as primary collector

> Organic reagents are promising options for depressing pyrite in seawater. However, further studies of their impact on the floatability of molybdenum should be conducted. Organic reagents may be used when recovery of molybdenum is not important

> The modified Denver cell allows the whole froth surface to be scraped at constant depth and rate. This increases the quality of the concentrate, and improves the reproducibility of the results

- The fast/slow-floating model is appropriate for describing the flotation kinetics of copper-molybdenum sulphide ores in seawater.

The parameters obtained from the fast/slow floating-model are useful for comparing flotation tests carried out under different conditions, since the $K$ indicator represents the global flotation performance. This takes into account simultaneously both maximum recovery and flotation rate.

\section{Acknowledgements}

The authors thank INNOVA CORFO Projects Csiro Chile 10CEII-9007, and L.A.C also thanks CONICYT and the Regional Government of Antofagasta for funding through the PAI programme, Project Anillo ACT 1201.

\section{References}

AKGul, D., CAKMaKc, M., KayaAlp, N., and Koyuncu, I. 2008. Cost analysis of seawater desalination with reverse osmosis in Turkey. Desalination, vol. 220. pp. 123-131.

BicAK, O., ЕкMEKCI, Z., BRADShaw, D.J., and HaRris, P.J. 2007. Adsorption of guar gum and CMC on pyrite. Minerals Engineering, vol. 20. pp. 996-1002.

Bournival, G., Pugh, R.J., and ATA, S. 2011. Examination of NaCl and MIBC as bubble coalescence inhibitor in relation to froth flotation. Minerals Engineering, vol. 25, no. 1. pp. 47-53.

Bulut, G., Ceylan, A., Soylu, B., and GoкTePE, F. 2011. Role of starch and metabisulphite on pure pyrite and pyritic copper ore flotation. Physicochemical Problems of Mineral Processing, vol. 48, no. 1. pp. $39-48$.

CASTRO, S. 2012. Challenges in flotation of Cu-Mo sulfide ores in sea water Proceedings of the 1st International Symposium: Water in Mineral Processing. Drelich, J. (ed.). SME, Englewood, CO. pp. 29-40.

CASTRo, S. and LASKowsKi, J.S. 2011. Froth flotation in saline water. Powder and Particle Journal, vol. 29. pp. 4-15.

Cisternas, L. and Moreno, L. 2014. Sea water in mining: fundamentals and applications. Master Rill, Santiago (in Spanish).

Forbes, E., DAvEY, K.J., and Smith, L. 2014. Decoupling rheology and slime coating effect on the natural floatability of chalcopyrite in a clay-rich flotation pulp. Minerals Engineering, vol. 56. pp. 136-144.

GHAfFour, N., Missimer, T.M., and Amy, G.L. 2013. Technical review and evaluation of the economics of water desalination: Current and future challenges for better water supply sustainability. Desalination, vol. 309 . pp. 197-207.
Hancer, M., CeliK, M.S., and Miller, J.D. 2000. The significance of interfacia water structure in soluble salt flotation systems. Journal of Colloid and Interface Science, vol. 235. pp. 150-161.

Jeldres, R.I., Arancibia-Bravo, M.P., Reyes, A., Aguirre, C.E., Cortes, L., and CisternAs, L.A. 2017. The impact of seawater with calcium and magnesium removal for the flotation of copper-molybdenum sulphide ores. Minerals Engineering, vol. 109. pp. 10-13.

Jeldres, R., Forbes, L., and Cisternas, L.A. 2016. Effect of seawater on sulfide ore flotation: a review. Mineral Processing and Extractive Metallurgy Review, vol. 37, no. 6. pp. 369-384.

Jeldres, R.I., Toledo, P.G., Concha, F., Stickland, A.D., Usher, S.P., and Scales, P.J. 2014. Impact of seawater salts on the viscoelastic behavior of flocculated mineral suspensions. Colloids and Surfaces A: Physicochemical and Engineering Aspects, vol. 461. pp. 295-302

Кон, P.T. and SмIтн, L.K. 2011. The effect of stirring speed and induction time on flotation. Minerals Engineering, vol. 24, no. 5. pp. 442-448.

Koleini, S.M., Abdollahy, M., and Soltani, F. 2012. The comparison between sodium cyanide and white dextrin as pyrite depressants in the sequential flotation $\mathrm{Cu}-\mathrm{Zn}$ massive sulphide ore-irantaknar. Proceedings of the 26 th International Mineral Processing Congress, New Delhi, India. 24-28 September 2012. Indian Institute of Metals. pp. 5120-5128.

KuRsun, H. 2014. Adsorption and flotation characteristics of the different types of frothers. Particulate Science and Technology, vol. 32. pp. 632-636.

LASKowsKi, J.S., CASTRo, S., and RAmos, O. 2014. Effect of seawater main components $\mathrm{n}$ frothability in the flotation of $\mathrm{Cu}-\mathrm{Mo}$ sulfide ore Physicochemical Problems of Mineral Processing, vol. 50. pp.17-29.

LeE, K., ARnot, T., and MatTiA, D. 2011. A review of reverse osmosis membrane materials for desalination-development to date and future potential. Journal of Membrane Science, vol. 370. pp.1-22.

LeIDNER, A.J., Rister, M.E., LACEWElL, R.D., WoodARD, J.D., and STURdivant, A.W. 2012. An analysis of input choice, input prices, and environmental factors on the costs of seawater reverse osmosis systems. Desalination, vol. 291. pp. 48-55.

Liu, R., Sun, W., Hu, Y., and WANG, D. 2009. Effect of organic depressant lignosulfonate calcium on separation of chalcopyrite from pyrite. Journal of Central South University of Technology, vol. 16. pp. 753-757.

López Valdivieso, A., Celedón Cervantes, T., Song, S., Robledo Cabrera, A., and LASKowsKI, J. 2004. Dextrin as a non-toxic depressant for pyrite in flotation with xanthates as collector. Minerals Engineering, vol. 17. pp. 1001-1006.

Lucay, F., Cisternas, L.A., Gálvez, E., and López-Valdivieso, A. 2015. Study of the natural floatability of molybdenite fines in saline solutions. Effect of gypsum precipitation. Minerals and Metallurgical Processing Journal, vol. 32. pp. 203-208.

Mermilled-Blondin, R., Kongolo, M., De Donato, P., BenzaAzous, M., Barres, O. Bussiere, B., and Aubertin, M. 2005. Pyrite flotation with xanthate under alkaline conditions-application to environmental desulfurization. Proceedings of the Centenary of Flotation Symposium, Brisbane, Queensland, 6-9 June 2005. Australasian Institute of Mining and Metallurgy, Melbourne. pp. 683-692.

MoNARDES, A. 2009. Use of seawater in grinding-flotation operations and tailing disposal. Proceedings of the XI Symposium on Mineral Processing Moly-Cop 2009

Mu, Y., PEnG, Y., and Lauten, R.A. 2015. Electrochemistry aspects of pyrite in the presence of potassium amyl xanthate and a lignosulfonate-based biopolymer depressant. Electrochimica Acta, vol. 174. pp. 133-142.

ORdoñes, J.J., Moreno, L., GÁlvEZ, E.D., and CisternAs, L.A. 2013. Sea water leaching of caliche mineral in column experiments. Hydrometallurgy, vol. 139. pp. 79-87.

Parraguez, L., Bernal, L., and Cartagena, G. 2009. Chemical study for selectivity and recovery of metals sulphides by flotation using seawater. Proceedings of the 6th International Mineral Processing Seminar, Santiago, Chile. pp. 323-333.

Ramos, O., CASTRo, S., and LaskowsKi, J.S. 2013. Copper-molybdenum ores flotation in seawater: Floatability and frothability. Minerals Engineering, vol. 53. pp. 108-112.

Sarquís, P.E., Menéndez-Aguado, J.M., Mahamud, M.M., and Dsioba, R. 2014 Tannins: the organic depressants alternative in selective flotation of sulfide. Journal of Cleaner Production, vol. 84. pp. 723-726.

UCURUM, M. and ВАYAT, 0. 2007. Effects of operating variables on modified flotation parameters in the mineral separation. Separation and Purification Technology, vol. 55. pp. 173-181.

VEKI, L. 2013. The use of seawater as process water in concentration plant and the effects on the flotation performance of Cu-Mo ore. Master's thesis, University of Oulu, Finland.

WANG, X-H. 1995. Interfacial electrochemistry of pyrite oxidation and flotation. II. FTIR studies of xanthate adsorption on pyrite surfaces in neutral $\mathrm{pH}$ solutions. Journal of Colloid and Interface Science, vol. 171. pp. $413-428$. 